\title{
The Changing Role of the Department Chair in the Shifting Landscape of Higher Education
}

\author{
Lisa D. Weaver ${ }^{1}$, Katherine $\mathrm{Ely}^{1}$, Loretta Dickson ${ }^{1} \&$ Jennifer DellAntonio ${ }^{1}$ \\ ${ }^{1}$ Lock Haven University, Lock Haven, PA, USA \\ Correspondence: Lisa D. Weaver, 116 Akeley Hall, Lock Haven University, Lock Haven, PA 17745, USA. E-mail: \\ lweaver@lockhaven.edu
}

Received: July 1, 2019

Accepted: July 23, 2019

Online Published: July 25, 2019

doi:10.5430/ijhe.v8n4p175

URL: https://doi.org/10.5430/ijhe.v8n4p175

\begin{abstract}
Historically, empirical research exploring the roles, responsibilities, and challenges of department chairs has been limited and narrow in scope. In addition, these studies have not kept pace with the rapidly changing nature of higher education. The current study consists of data collected from a survey of current and former chairs at a small, rural university in Pennsylvania. Questions in the survey included topics such as dealing with bureaucracy, lack of time for individual research, job-related stress, dealing with noncollegial faculty, excessive workload, and training for department chairs. Findings are in line with previous empirical research and illustrate the need for evidence-based decisions regarding the nature of academic department chair leadership training and support.
\end{abstract}

Keywords: department chair, higher education, leadership training, professional development, academic leadership

\section{Introduction}

Higher education institutions are struggling to address the challenges of increasing costs and reduced funding, increased competition between colleges and universities, changes in student demographics, decreased enrollments, and lack of diversity. The radically changing landscape of higher education and its impact on the nature of academic leadership is demonstrated in the changing role of the academic department chair. According to Riley and Russell (2013), new department chairs will find their role much more complex than they would have just a decade ago.

Department chairs have a very strategic and challenging position since a great deal of work at universities is completed at this level. Department chairs are tasked with curriculum planning, performance reviews, fiscal oversight, advocating for and representing their department to the university at large and to external constituents. Clearly, department chairs require skills different from those that originally attracted them to the independent life of a scholar and require leadership responsibilities that differ from those of their predecessors.

Despite such arduous and complex nature of their work, department chairs usually come to the position without going through any preparation for current leadership practices. For example, Cipriano and Riccardi (2012) found that only 3.3 percent of department chairs had formal coursework related to leadership strategies in their education and only 9.1 percent had formal training on managing an academic department.

The reality is the need to consider the great deal of academic and administrative problems department chairs are more likely to face when they come to the position. However, there is little research focusing on academic leadership, specifically chairships, at the higher education level in Pennsylvania. In addition, only a few existing studies used the specific term; academic leadership and none use the term, department chairs.

The purpose of this study was to examine the changing role of the department chair as institutions move toward a more sustainable pathway. In conducting a survey of faculty members who served or are serving as department chairs, and asking about their roles, responsibilities, and training, the hope was to provide clarity to the role as well as potential areas for leadership skill preparation.

\section{Historical Background of Literature Review}

Empirical research exploring the roles and responsibilities of department chairs has been limited and narrow in scope, although books have been written that illustrate the complexity and ambiguity of the chair role. Allan Tucker completed one of the first scholarly examinations of the role of the chair centering most of his research on academic leadership. In 1981, Tucker published the first edition of Chairing the Academic Department: Leadership among 
Peers. For many years, this document was the only academic text on issues faced by academic department leaders. Tucker's book was known for its in-depth portrayal of a departmental leader's roles and responsibilities. Tucker's seminal work was revised and published again in 1984 and 1992.

Following Tucker's death, other authors trailed with research on the work of the department chair. For example, in 1993, Gmelch and Miskin published a book titled Leadership Skills for Department Chairs. This academic exploration into the characteristics of the chair's role identified four major themes: manager, leader, faculty developer, and scholar. In addition, Gmelch and Miskin (1993) recognized the opportunity of chairs to encourage scholarship, and support talent and productivity within academic departments.

In 1994, Ann Lucas published her book titled Strengthening Departmental Leadership: A Team-Building Guide for Chairs in Colleges and Universities. Lucas contends, "academic leaders may be the least studied and most misunderstood position in the world" (p. 6). In her publication, Lucas (1994) tackled topics such as communication, personal relationships, and team-building skills. She emphasized the art and science of leadership skills, specifically, the ability to motivate faculty, thus increasing productivity in various areas such as teaching and scholarship.

In 1999, Hecht, Higgerson, Gmelch, and Tucker (1999) collaborated on the book titled The Department Chair as Academic Leader. The historical perspective on higher education leadership for the last sixty years revealed that the department chair was the "primary agent for reforming and contemporizing American higher education" (p. xiv). The role of chair was noted as becoming more complex and requiring an expanded skill set.

Finally, and more recently, N. Douglas Lees offers Chairing Academic Departments: Traditional and Emerging Expectations (2006). Lees explores the traditional roles of department chairs and offers tips on success as a $21^{\text {st }}$ century chair with a penchant for embracing change. This includes creating opportunities for faculty growth and productivity in the contemporary world (p. 18). According to Lees, chairs will increasingly be called upon to develop innovative programs, seek new revenue streams and external funding sources, and play more active roles in recruiting students and designing programs to retain them (pp. 17-18).

Many other authors contributed to the research of Allan Tucker $(1981,1991,1992)$ and support the belief that chairs are leaders and managers among faculty peers. New research after Tucker (1981) suggested the chair's roles and responsibilities transcend beyond that of the institution. Furthermore, it is asserted that the chair's responsibilities are more complex and challenging than ever before and certainly more so since the writings of Tucker in 1981 (Downey, D., 2018; Evans \& Chun, 2015; Franklin \& Hart, 2006; Lucas, 1994; Troester \& Wertheimer 2015).

\subsection{Chair's Roles and Responsibilities}

As mentioned earlier, Tucker (1981) was one of the first scholars to investigate the work of a department chair's various tasks. He outlines 54 tasks and explains how chairs could quite possibly undertake as many as 28 roles, either one role at a time or several roles simultaneously. The 28 roles expanded to 41 roles by the 1992 publication of Tucker's work (Tucker, 1992). 
Table 1. Tucker's (1981) Department Chair Tasks and Duties (pp. 2-4) @ 1981, American Council on Education. Used with permission.

\begin{tabular}{|c|c|}
\hline Category & Tasks and Duties \\
\hline $\begin{array}{l}\text { Department } \\
\text { governance }\end{array}$ & $\begin{array}{l}\text { Conduct department meetings; Establish department meetings; Use committees effectively; } \\
\text { Develop long-range department programs, plans, and goals; Determine what services the } \\
\text { department should provide to the university, community, and state; Implement long-range } \\
\text { department programs, plans, goals, and policies; Prepare the department for accreditation } \\
\text { and evaluation; Serve as an advocate for the department; Monitor library acquisitions; } \\
\text { Delegate some department administrative responsibilities to individuals and committees; } \\
\text { Encourage faculty members to communicate faculty ideas for improving the department. }\end{array}$ \\
\hline Instruction & $\begin{array}{l}\text { Schedule classes; Supervise off-campus programs; Monitor dissertations, prospectuses, and } \\
\text { programs of study for graduate students; Supervise, schedule, monitor, and grade } \\
\text { department examinations; Update department curriculum, courses, and programs. }\end{array}$ \\
\hline Faculty Affairs & $\begin{array}{l}\text { Recruit and select faculty members; Assign faculty responsibilities such as teaching, } \\
\text { research, committee work, and so forth; Monitor faculty service contributions; Evaluate } \\
\text { faculty performance; Initiate promotion and tenure recommendations; Participate in } \\
\text { grievance hearings; Make merit recommendations; Deal with unsatisfactory faculty and } \\
\text { staff performance; Initiate termination of a faculty member; Keep faculty members } \\
\text { informed of department, college, and institutional plans, activities, and expectations; } \\
\text { Maintain morale; Reduce, resolve, and prevent conflict among faculty members; Encourage } \\
\text { faculty participation. }\end{array}$ \\
\hline Student Affairs & Recruit and select students; Advise and counsel students; Work with student government. \\
\hline $\begin{array}{c}\text { External } \\
\text { Communication }\end{array}$ & $\begin{array}{l}\text { Communicate department needs to the dean and interact with upper-level administrators; } \\
\text { Improve and maintain the department's image and reputation; Coordinate activities with } \\
\text { outside groups; Process department correspondence and requests for information; Complete } \\
\text { forms and surveys; Institute and maintain liaison with external agencies and institutions. }\end{array}$ \\
\hline $\begin{array}{l}\text { Budget and } \\
\text { Resources }\end{array}$ & $\begin{array}{l}\text { Encourage faculty members to submit proposals for contracts and grants to government } \\
\text { agencies and private foundations; Prepare and propose department budgets; Seek outside } \\
\text { funding; Administer the department budget; Set priorities for use of travel funds; Prepare } \\
\text { annual reports. }\end{array}$ \\
\hline $\begin{array}{c}\text { Office } \\
\text { Management }\end{array}$ & $\begin{array}{l}\text { Manage department facilities and equipment, including maintenance and control of } \\
\text { inventory; Monitor building security and maintenance; Supervise and evaluate the clerical } \\
\text { and technical staff in the department; Maintain essential department records, including } \\
\text { student records. }\end{array}$ \\
\hline $\begin{array}{l}\text { Professional } \\
\text { Development }\end{array}$ & $\begin{array}{l}\text { Foster the development of each faculty member's special talents and interests; Foster good } \\
\text { teaching in the department; Stimulate faculty research and publications; Promote } \\
\text { affirmative action; Encourage faculty to participate in regional and national professional } \\
\text { meetings; Represent the department at meetings of learned and professional societies. }\end{array}$ \\
\hline
\end{tabular}

Noted in Table 1 are the 8 categories, tasks and duties developed by Tucker (1981).

A study conducted by Chu and task force committee members (2005) titled Roles and Responsibilities of Chairs at the California State University revealed the following findings:

Many of the chairs who responded to the survey had a different view of how much they knew about the position before they assumed it. Only $16 \%$ of respondents reported that their deans gave them clear written expectations for their performance. Twenty-five percent indicated that their deans gave them clear expectations verbally, and 57\% reported that their deans gave them no performance expectations. Whether or not this means that they were not given a written job description, or they were not given clear expectations of how they were to fulfill the duties and responsibilities outlined in a job description cannot be discerned. In either case, the responses on the surveys suggested that many chairs felt that they were "flying blind" in terms of what was expected of them. (p.12) 
Although this research study was administered at one institution and the generalizability of findings limited, it is possible that given the results of the study, the roles and responsibilities are as ambiguous to department chairs today as they were in 1972. More recently, Jones (2011) studied the competencies of department chairs needed for the future. Results indicate department chairs need to be highly competent and multitask competencies for success in this role. The competencies identified indicate more of a focused need on leadership than management and tasks.

Table 2. Suggested Roles and Responsibilities of Department Chair (Jones, 2011). Used with permission.

\begin{tabular}{|c|c|}
\hline Name of Role & Suggested Roles and Responsibilities \\
\hline Administrator/Supervisor & $\begin{array}{l}\text { Accountability, budgeting and finance; Organizing, tracking, and reporting } \\
\text { department activities; Personnel Management }\end{array}$ \\
\hline Instructor, Trainer, and Teacher & Managing the curriculum; Managing teaching and instruction \\
\hline Mediator and Negotiator & Mediating and negotiating; Handling legal and disciplinary issues \\
\hline Representative and Politician & Dealing with internal and external audiences \\
\hline Communicator & Internal and external communication with constituents \\
\hline Motivator & Motivating, improving, and rewarding faculty and staff \\
\hline Developer and Planner & $\begin{array}{l}\text { Faculty development; Student development; Goal setting, strategic planning, and } \\
\text { forecasting }\end{array}$ \\
\hline Evaluator and Assessor & $\begin{array}{l}\text { Evaluating the department and individual programs; Evaluating personnel (faculty } \\
\qquad \& \text { staff); Evaluating students }\end{array}$ \\
\hline Recruiter & Recruiting and hiring faculty \\
\hline $\begin{array}{l}\text { Manager, Problem Solver, } \\
\text { Facilitator }\end{array}$ & Conflict management; Managing people \\
\hline Leader & Change management; Leading the department \\
\hline Survivor & Personal survival and development \\
\hline
\end{tabular}

In Table 2, Jones (2011) outlines the roles and responsibilities of department chairs.

\subsection{Chair Challenges}

Faculty taking on the position of chair experience abrupt changes in their work life, adding to the stresses of their academic career. The challenges are compounded by the fact that chairs come out of their teaching roles in disciplines that may be a far cry from management and leadership, thus leaving them underprepared. Graduate school prepares a professor for the life of a scholar and for research within a discipline. For example, Cipriano and Riccardi (2010) surveyed chairs with over $50 \%$ of respondents reporting the following five major challenges: dealing with bureaucracy, lack of time for individual research, job-related stress, dealing with noncollegial faculty, and excessive workload. The challenges are also magnified because most chairs have no formal preparation for the position. Many experts recommend leadership and management training for chairs. Further studies suggest the most effective leadership program is created on the solid foundation of a well-defined leadership model including cohort groups of chairs and administrators and encompasses an ongoing relationship and constructive feedback on a continuous basis (Detmer-Goebel, 2015; Gmelch \& Misken, 2004).

Gmelch \& Buller (2016) explored skill development needed for taking on the role of department chair. Often the average chair is in an unknown situation and faced with the need of immediate on-the-job training and skill sets not previously used in the faculty role. Other studies indicate that academic chairs must possess leadership capabilities including expert communication skills, conflict management abilities, critical thinking and problem-solving skills. Interestingly, this list of requirements reflects the common requisites offered in business school curriculum where many CEOs and other business managers receive their initial management and leadership training (Hecht, Higgerson, Gmelch, \& Tucker, 1999; Lucas, 1994; Tucker, 1992; Wolverton \& Penley, 2004).

A comprehensive study conducted by the University Council for Educational Administration in 2016, surveyed new department chairs and learned that $67 \%$ did not receive any training once appointed and, of those who did receive training, $40 \%$ received less than four hours. This lack of training contributes to unnecessary stress for chairs, as well 
as feelings of incompetency. This study also reported the following: $41 \%$ of chairs felt competent by the ninth month, $40 \%$ did not feel competent until the end of their first or second year, and 19\% took even longer to feel competent as a chair.

This compounding effect is supported by Boyko (2009) who asserts that chairs be given the opportunity to attend educational seminars, conferences, professional development workshops or other formal training in specific managerial topics. Additional resources and training opportunities should be available on an as-needed basis. Other challenges of the chair role are depicted by Gmelch and Burns (1994), who compare the transition from faculty to chair responsibilities to the role of Janus, a Roman God with two faces looking in two directions at the same time. Gmelch and Burns (1994) stated "According to the mythology Janus had two faces: one face was turned to the front and the other to the back. Academic chairpersons may very well hold the same stance; one face represents the role of administrator/manager/leader and the other that of academic faculty member." Often, chairs are at the center of the tension between faculty and administration. They mediate the interests of the university mission and goals, at the same time, they try to advocate for the needs of their faculty (Gmelch \& Miskin, 2004).

In summary, this review indicates that the empirical research literature on academic department chairs has not kept pace with the rapidly changing nature of higher education. Given the significant and important institutional roles that department chairs perform, more research needs to be conducted on contemporary problems and issues to provide evidence-based decisions regarding the nature of academic department chair leadership training. Despite the pressing need for leadership development, many institutions of higher education provide minimal preparation for department chairs.

\section{Method}

This research was conducted using data collected from a survey of current and former chairs at a small, rural university in Pennsylvania (see Appendix). The sampling frame was created based on combining lists of current and previous department chairs and identifying if they had a valid email address to be contacted about the study. A total of 143 names were listed, but the survey was sent to 75 individuals due to incomplete contact information. The survey was administered online via SnapSurvey software. A link to the survey was emailed to the selected participants multiple times over a 7 -week period. A total of 34 individuals responded for a response rate of $45 \%$.

Questions in the survey were divided into the following categories: meeting attendance outside department, overall university technology support, economic changes, student enrollment, scholarship, chair orientation, leadership training, interdepartmental relationships, relationships within the department, contact with administrators, department priorities and goals, nature of chair meetings, annual review process, assessment, curricular process, release time, faculty lines, and travel and purchasing. Demographic questions included size of department, length of chair term, and year of first becoming chair. No other demographic questions were included due to the small sample size and the ability to identify participants based on this information and their responses. Out of the 34 respondents, 18 identified the year they first became chair: 1970, 1981, 2000, 2002 (2), 2003, 2005, 2006, 2008, 2011 (3), 2017 (4), and 2018.

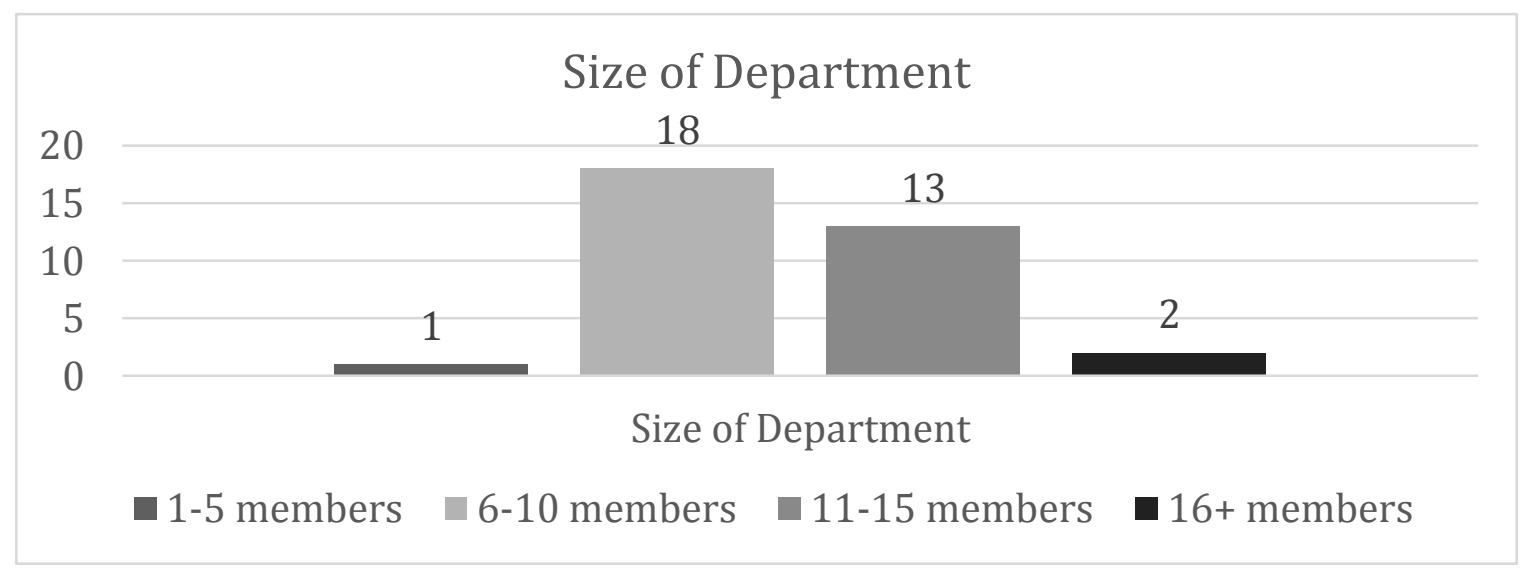

Figure 1. Department size

Description: As you can see the majority of the respondents come from fairly large departments of 6-10 members or 11-15 members. 


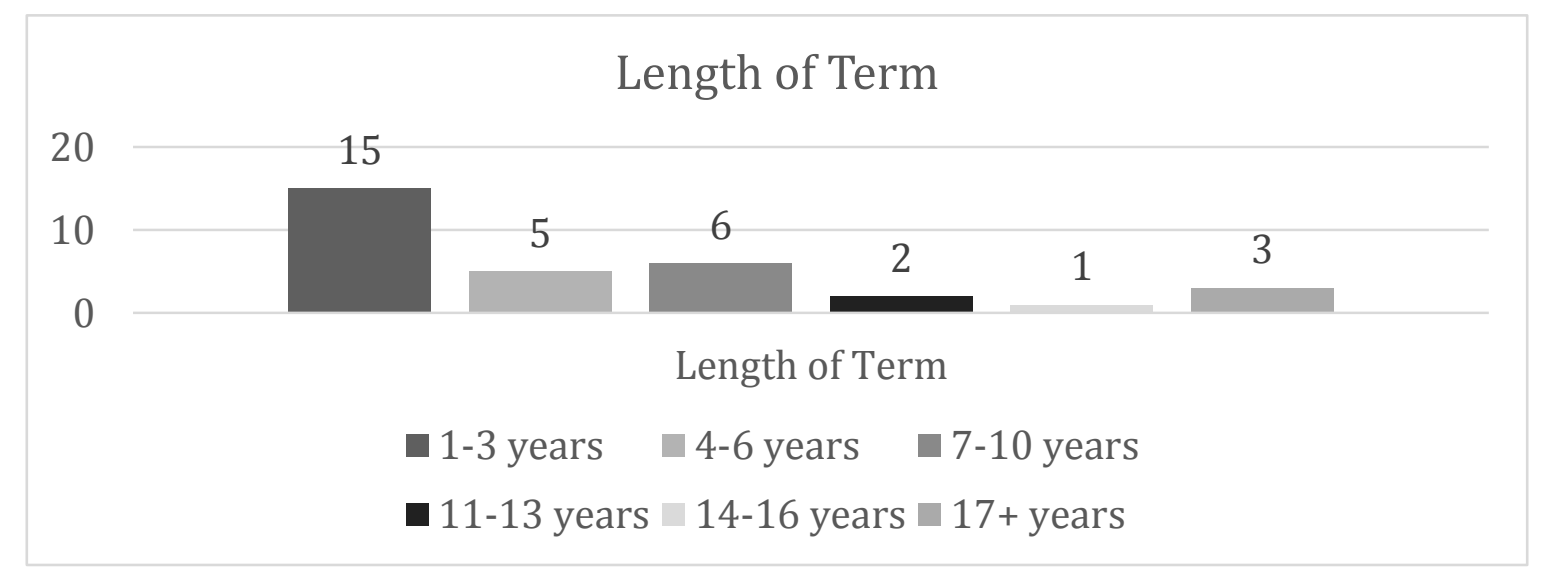

Figure 2. Length of term

Description: The majority of respondents served a term length of 1-3 years.

\section{Results}

Since this study was more exploratory and descriptive in nature, we present mostly descriptive statistics for the quantitative analysis. However, qualitative results are also included where participants provided detailed responses. A summary of the findings is highlighted below.

\subsection{Economic Changes and Student Enrollment}

Thirty one percent of participants felt the economic status of the university had a moderate effect on decisions made by the chair, while $56 \%$ felt it had a major effect. The majority of respondents $(76 \%)$ felt that the department chair is slightly or somewhat influential in affecting enrollment. Forty-four percent felt mostly or completely responsible for recruitment of new students. In terms of being consulted about recruitment, $38 \%$ reported sometimes and $26 \%$ reported often being consulted about recruitment by admissions. It is also evident that enrollment is a major concern for department chairs, as $47 \%$ of the participants were extremely concerned with enrollment during their time as chair.

\subsection{Scholarship and Release Time}

Slightly more than half $(56 \%)$ of the participants felt that serving as department chair was a barrier to conducting and publishing research. In addition, $32 \%$ indicated research was not a priority, and 38\% indicated research was a low priority during time as chair. Half of the participants indicated that they are very dissatisfied or dissatisfied with the amount of release time they receive as chair. If no release time were offered, $94 \%$ would be extremely unlikely or unlikely to have interest in the department chair position.

\subsection{Chair Orientation and Leadership Training}

Out of the participants, 59\% indicated there was an orientation to attend when they first became department chair. In some instances, orientation was not available for new chairs, but $58 \%$ indicated they would have gone if there was one available. Out of those who attended new chair orientation, $65 \%$ felt the orientation was helpful or very helpful. Being mentored by the previous chair was another important factor in becoming orientated to the role of department chair. However, according to the survey data, the previous chair did not mentor $56 \%$ of the participants.

In terms of leadership training, $85 \%$ did not participate in leadership training at the University prior to becoming chair, although $69 \%$ said it was likely or extremely likely they would have attended one. For those that did attend, $44 \%$ identified it as being helpful. Prior to becoming chair, 51\% participated in leadership training outside of the University, and $47 \%$ indicated it was likely or extremely likely they would have attended one. Most identified this training as helpful or very helpful (74\%). Once becoming chair, $29 \%$ participated in leadership training at the University, and even less participated in leadership training outside of the University (26\%).

\subsection{Interdepartmental and Departmental Relationships}

Interdepartmental networking was identified as a medium (41\%) and high (26\%) priority. However, most respondent's perception of interdepartmental comradery was more neutral (38\%) than positive or 
negative. Interestingly, one person who noted that these interdepartmental relationships are extremely important identified the comradery in their department to be very negative.

For those folks who identified this networking as a medium priority (41\%), the perception was almost equally distributed. Of note however, are the comments folks made who felt it was neutral or negative. One individual, who perceived it to be negative, felt that "administrative decisions had pitted departments against one another" while another was "softer" in their assertion that "administration does not encourage positive collaboration between departments." Two individuals whose perception of comradery was neutral shared their thoughts of "depending on departments, it is challenging when some departments view others as threats;" and that "relationships with departments in other colleges were less positive, likely due to lack of contact." A final note is a chair that felt interdepartmental networking is a high priority and their perception is that it is very positive, added the following comment..." interdepartmental comradery is affected by the tone set by the administration. When I was chair the atmosphere was good. Now it is not."

Collegial relationships within the department were rated as Poor (9\%), Fair (23\%), Good (21\%), Very good (35\%), and Excellent (12\%). While most chairs indicated that they were very welcomed by both the previous department chair and the department members, more individuals indicated being not welcomed by the previous chair (15\%) compared to not being welcomed by the department (3\%). It is also apparent that departments more likely than not experienced conflict (53\% sometimes, $14 \%$ often, $12 \%$ always). However, the climate was rated more positive than negative (38\% friendly, $21 \%$ cordial, $18 \%$ polite).

Regarding poor relationships within the department, only two chairs elaborated on the relationships and both shared their concerns with lack of management action: "years of in-fighting among faculty that has never been resolved by management" and "my department is extremely volatile. There are regular outbreaks among faculty in front of students. The previous dean was informed of the hostile environment; however, nothing has been done." Another chair that stated that the relationships are very good within the department did share that "in the midst of being lied to by administration and betrayed by other departments, the department maintained a friendly atmosphere amongst one another." Even when two folks identified a faculty member within their department who may have presented as divisive or mercurial, they still identified the climate as friendly/polite and the collegial relationships as excellent/good.

\subsection{Chair Responsibilities}

When asked about meetings that department chairs need to attend, $85 \%$ of the respondents agreed or strongly agreed that the number of meetings outside of the department have increased. In addition, these meetings are medium (53\%) or high $(32 \%)$ priority. Almost all of the participants indicated that they had regularly scheduled meetings with the Dean. Most commonly, these were held every other week or once a month. Most respondents indicated that the Dean set the agenda for chair meetings (62\%), while the remainder said it was a collaborative effort.

The majority of chairs felt mostly (35\%) or completely (50\%) responsible for writing the department/program annual report. In addition to their role as department chair, $44 \%$ of the chairs were responsible for department/program assessment. In terms of the curricular process, $44 \%$ of the chairs were moderately or extremely familiar with the curricular process before becoming chair. Almost three quarters of the respondents (74\%) felt satisfied or very satisfied with chair involvement in the curricular process.

\subsection{Other Chair Concerns}

A few questions in the survey asked participants about other concerns, such as overall university technology support, faculty lines, and money provided to the department faculty for travel. The majority of participants (76\%) were satisfied or very satisfied with the level of support they received regarding technology. Slightly more than half $(53 \%)$ of the chairs had the majority of their faculty as tenured or tenure track during their time as chair. Finally, money for travel was generally allocated once per academic year, although $9 \%$ stated it was once a semester.

\section{Statistics}

Based on the survey responses, we were able to run some bivariate correlations. 
Table 3. Significant correlations

\begin{tabular}{|c|c|c|}
\hline \multicolumn{2}{|c|}{ Variables } & \multirow{2}{*}{$\begin{array}{l}\text { Correlation } \\
\text { Coefficient }\end{array}$} \\
\hline & & \\
\hline Climate in department & Collegial relationships & $.821 * *$ \\
\hline Conflict in department & Interdepartmental comradery & $-.599 * *$ \\
\hline Welcomed by previous chair & Mentored by previous chair & $.567 * *$ \\
\hline Climate in department & Conflict in department & $-.515 * *$ \\
\hline Responsible for enrollment & Concern with enrollment & $.501 * *$ \\
\hline Leadership training outside the University & Length of term & $.490^{*}$ \\
\hline Collegial relationships in department & Mentored by previous chair & $.486^{* *}$ \\
\hline Leadership training at the University & Length of term & $.456^{* *}$ \\
\hline Satisfaction of role in curricular process & $\mathrm{DC}$ as barrier to research & $-.382 *$ \\
\hline Department size & Leadership training after being chair & $-.367 * *$ \\
\hline Collegial relationships & Interdepartmental networking & $.367^{*}$ \\
\hline
\end{tabular}

$* p<0.05$

$* * p<0.01$

Description: Table 3 illustrates the strongest significant correlations.

There were a number of significant correlations related to department climate and collegial relationships. A more positive climate in the department is related to less conflict as well as more collegial relationships. More conflict in the department is related to less interdepartmental comradery. When there are collegial relationships within the department, there is more interdepartmental networking. In addition, more collegial relationships often contribute to an increase in mentoring by the previous chair. If individuals felt welcomed by the previous chair, it was also likely that that person mentored them as well.

There were some significant correlations related to leadership training. Individuals who served longer department chair terms tended to participate in leadership training outside of the University. Another interesting finding was that as department size increased, it was less likely that chairs went to leadership training after becoming chair.

Finally, there were some significant correlations related to other issues faced by chairs. If chairs had a higher concern with enrollment, they tended to feel more responsible for it as well. In addition, if chairs were less satisfied with their role in the curricular process, they tended to view being department chair as a barrier to conducting research.

\section{Discussion}

Our research focused on the changing role of the department chair and the needs identified by past and current chairpersons. The challenges found by Cipriano and Riccardi (2010) were replicated in our research, such as dealing with bureaucracy, lack of time for individual research, job-related stress, dealing with noncollegial faculty, and excessive workload.

Our findings mirrored some of those we identified in our literature review and suggest the role of the department chair continues to be a complex one. We believe the participant's experiences offer valuable insights into the past and current role of chairs, despite the relatively small number of participants and the specific university context associated with exploratory and descriptive nature of this study. In addition, it supports the existence of multiple factors inherent of the chair's role transition and success into a managerial role that provoke ambiguity, uncertainly and lack of training.

The overall results of the study indicate that the struggle current chairs face compared to chairs of the past are economic changes to the overall university structure with increased administrative responsibilities, need for leadership training and lack of time to devote to professional development.

Literature in the role of the chair indicates that leadership training is an important component in preparing chairs with the knowledge they need to best serve the University. Leadership training for department chairs has been identified as desired and helpful (Detmer-Goebel, 2015; Gmeltch \& Misken, 2004). While the majority of participants in our study had attended an orientation, most of them would have liked to participate in leadership training prior to becoming a department chair. 
While participation in leadership training is low among department chairs, the survey did indicate that some activity does, occur, although infrequent. Some of participants had engaged at least once in direct orientation to the role of the chair. However, most of the participants did not receive ongoing training. While the department chairs had some opportunity, most have never attended a seminar or workshop where they could receive training. Universities should provide orientation and ongoing training support for department chairs on a regular, sustained basis. Involving department chairs in leadership support will reap benefits to the university as a whole.

Currently, one of the major roles of the university department chair is keeping pace with the revolutionary changes in technology, knowledge management and communication that has characterized higher education of the $21^{\text {st }}$ century. Although academic department chairs past and present share similar qualities, their necessary roles and skill sets now differ markedly. Tucker (1992) noted important traits of the department chair, which are highlighted in Table 1 . The emphasis today is the department chair's ability to adapt to change, understand the economic status of their university and impact on enrollment (Jones 2011; Gmelch \& Buller, 2016). A few examples would be financial constraints, declining enrollments, productivity and accountability reports, fund raising, and changing technology.

Today's universities face ongoing challenges such as declining enrollment, decreased funding, and external demands for reform and accountability (Armstrong \& Woloshyn, 2017). The impact of these challenges requires innovative forms of leadership on the role of the chair in order to succeed. Universities may be able to give more support to department chairs by creating a support group or a committee where department chairs across disciplines meet regularly and discuss issues that they face. Furthermore, it may be beneficial to send department chairs to a formal leadership program, such as, ACE Leadership Academy (American Council on Education, 2015), which is specifically designed for midlevel newly appointed leaders in higher education.

One area of research that could be advanced would involve only current department chairs. Asking for specific areas where they feel under-trained or lacking knowledge in order to develop relevant and comprehensive leadership skills for chairs. As "front-line" supervisors, it is vital for University sustainability to provide chairs with ongoing strong leadership training and support for the challenges they continue to face.

\section{References}

Armstrong, D. D. \& Woloshyn, V. E. (2017). Exploring the tensions and ambiguities of university department chairs. Canadian Journal of Higher Education, 47(1), 97-113.

Boyko, L. (2009). An examination of academic department chairs in Canadian universities. Journal of Educational Administration, 32(1), 79-94.

Chu, D., Kessler, G., Klein, M., Montanari, D., Ontiveros, C., Wort, D. \& Veregge, S. (2005). Roles, responsibilities, resources, and rewards for department chairs: A report to the academic senate, California State University from the Task Force on Roles Responsibilities of Chairs. Retrieved June 11, 2018, from the California State Academic Senate Records Web site: http://www.calstate.edu/AcadSen/Records/Reports/ RolesRespRwrds-DptChairs.pdf

Cipriano R \& Riccardi R (2010). What is unique about chairs? A continuing exploration. The Department Chair, 20(4), 26-28.

Cipriano R \& Riccardi R (2012). A continuing examination of the unique department chair. The Department Chair, 22(3), 9-11.

Detmer-Goebel, E. (2015). Informal support groups for chairs. The Department Chair, 26(2), 8-9. https://doi.org/10.1002/dch.30045

Downey, D. J. (2018). Faculty composition and the chair's role: Considering the challenges and Opportunities of a junior-heavy department. The Department Chair, 28(3), 21. https://doi:10.1002/dch.30177

Evans, A. \& Chun, E. (2015). Department chairs as rransformational diversity leaders. The Department Chair, 25(3), 1-3. https://doi.org/10.1002/dch.30001

Franklin, K. \& Hart, J. (2006). Influence of web-based distance education on the academic department chair role. Journal of Educational Technology \& Society, 9(1), 213-228.

Gmelch, Dr. Walter H. (2015). Leading from the Middle: Managing Your Dean...and Others. Academic Chairpersons Conference Proceedings. http://newprairiepress.org/accp/2015/Keynote/1

Gmelch, W. H. \& Burns, J.S. (1991). Sources of stress for academic department chairs: A national study. ASHE Annual Meeting Paper. 
Gmelch, W. H. \& Buller, J. L. (2016). Skill development for academic leaders. The Department Chair, 26(3), 25-27. https://doi.org/10.1002/dch.30082

Gmelch, W. H. \& Miskin, V. D. (2004). Chairing an academic department (2 ${ }^{\text {nd }}$ ed.). Madison WI: Atwood Publishing.

Gmelch, W. \& Burns, J. (1994). Sources of stress for academic department chairs. Journal of Educational Administration, 32(1), 79-94. https://doi.org/10.1108/09578239410051862

Gmelch, W., Roberts, D., Ward, K. \& Hirsch, S. 2017. A retrospective view of department chairs: Lessons learned. The Department Chair, 28(1): 1-4. https://doi.org/10.1002/dch.30140

Hecht, I., Higgerson, M., Gmelch, W. \& Tucker, A. (1999). The department chairs as academic leader. Phoenix, AZ: Onyx Press.

Hubbell, A. \& Homer, A. (1997). The academic department chair: The logic of appeasement. Political Science and Politics, (2), 209. https://doi.org/10.2307/420497

Jones, F. R. (2011). The future competencies of department chair: A human resources perspective. Retrieved June 24, 2018 from https://diginole.lib.fsu.edu/islandora/object/fsu:181758/datastream/PDF/view

Kastor, J. A. (2013). Chair of a department of medicine: Now a different job. Academic Medicine: Journal of The Association f American Medical Colleges, 88(7), 912-913. https://doi.org/10.1097/ACM.0b013e318294ff56

Lees, N.D. (2006). Chairing academic departments: Traditional and emerging expectations. Bolton, MA: Anchor Publishing.

Lucas, A. F. (1994). Strengthening departmental leadership: A team-building guide for chairs in colleges and universities. San Francisco CA: The Jossey-Bass Higher and Adult Education Series.

Riley, T. A. \& Russell, C. (2013). Leadership in higher education: Examining professional development needs for department chairs. Review of Higher Education \& Self-Learning, 6(21), 38-57.

Schwinghammer, T. L., Rodriguez, T. E., Weinstein, G., Sorofman, B. A., Bosso, J. A., Kerr, R. A. \& Haden, N. K. (2012). AACP strategy for addressing the professional development needs of department chairs. American Journal of Pharmaceutical Education, 76(6), 1-8. https://doi.org/10.5688/ajpe766S7

Seagren, A. T., Creswell, J. W. \& Wheeler, D. W. (1993). The department chair: New roles, responsibilities and challenges. Washington, DC: George Washington University, School of Education and Human Development.

Şükrübellibaş, M. M., Özaslan, G. O., Gümüş, E. E. \& Gümüş, S. G. (2016). Examining department chairs' needs in performing academic leadership in Turkish Universities. Education \& Science, 41(184), 91-103. https://doi.org10.15390/EB.2016.6114

Troester, R. \& Wertheimer, M. (2015). The blending of the traditional and professional approaches to communication: Department chairs share administrative challenges, opportunities and best practices. Journal of the Association for Communication Administration, 34(1), 2-11.

Tucker, A. (1981). Chairing the academic department: Leadership among peers. Washington, DC: American Council on Education.

Tucker, A. (1991). Chairing the academic department: Leadership among peers ( $2^{\text {nd }}$ ed.). Washington, DC: American Council on Education.

Tucker, A. (1992). Chairing the academic department: Leadership among peers $\left(3^{\text {nd }}\right.$ ed.). Washington, DC: American Council on Education.

Wolverton, M. \& Penley, M. (2004). Elite MBA programs at public universities: How a dozen innovative schools are redefining business education. Westport, CT: Praeger Publishers.

Wolverton, M., Gmelch, W, Wolverton, M. \& Sarros, J. (1999). A comparison of department chair tasks in Australia and the United States. Higher Education, 38(3), 333-350. https://doi.org/10.1023/A:1003710427124 


\section{Appendix: Changing Role of the Department Chair Questionnaire and Responses}

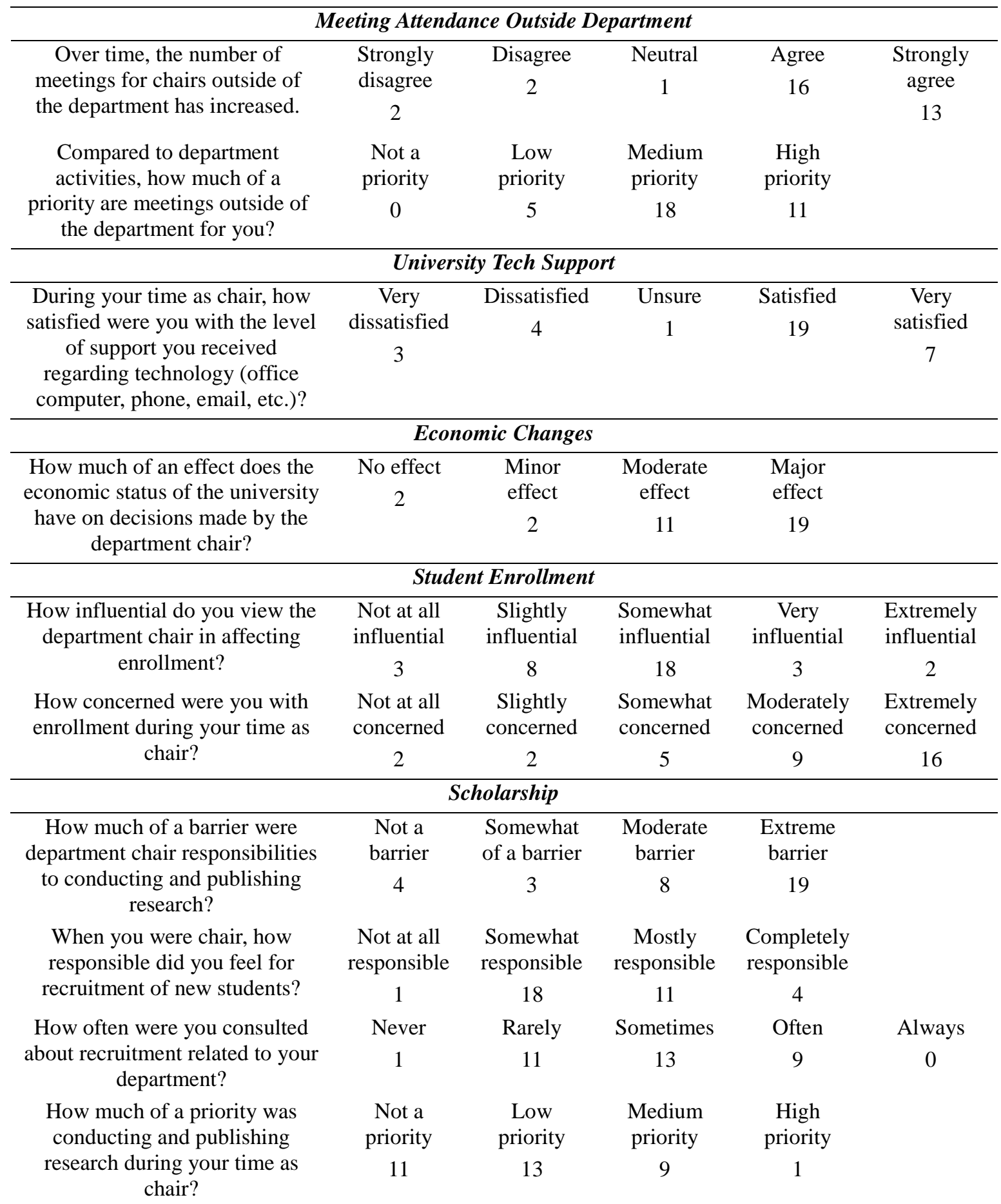

\begin{tabular}{|c|c|c|c|c|c|}
\hline \multicolumn{6}{|c|}{ Chair Orientation } \\
\hline When you became department & Yes & No & Not sure & & \\
\hline $\begin{array}{l}\text { chair, there was an orientation } \\
\text { for you to attend? }\end{array}$ & 20 & 11 & 3 & & \\
\hline If no, if there was one that was & Extremely & Unlikely & Neutral & Likely & Extremely \\
\hline $\begin{array}{c}\text { available, how likely is it that } \\
\text { you would have gone? }\end{array}$ & $\begin{array}{c}\text { unlikely } \\
0\end{array}$ & 0 & 2 & 6 & $\begin{array}{l}\text { likely } \\
11\end{array}$ \\
\hline If yes, how helpful was the & Very & Unhelpful & Neither & Helpful & Very \\
\hline
\end{tabular}




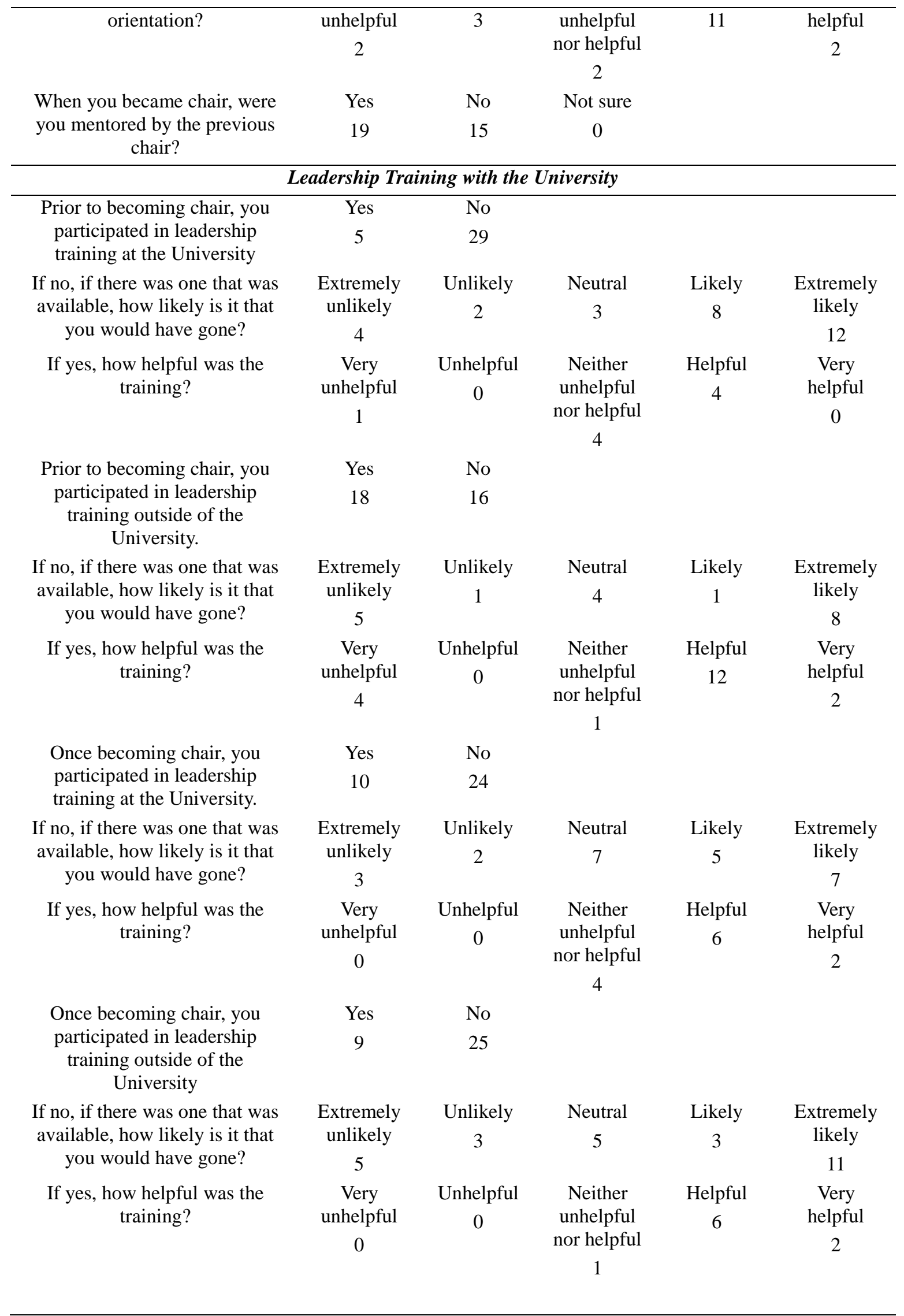




\begin{tabular}{|c|c|c|c|c|c|}
\hline \multicolumn{6}{|c|}{ Interdepartmental Networking or Comradery } \\
\hline \multirow{5}{*}{$\begin{array}{l}\text { How much of a priority was } \\
\text { interdepartmental networking? } \\
\text { How did you perceive } \\
\text { interdepartmental comradery? }\end{array}$} & $\begin{array}{l}\text { Not a } \\
\text { priority }\end{array}$ & $\begin{array}{l}\text { Low } \\
\text { priority }\end{array}$ & $\begin{array}{l}\text { Medium } \\
\text { priority }\end{array}$ & $\begin{array}{l}\text { High } \\
\text { priority }\end{array}$ & \\
\hline & 2 & 9 & 14 & 9 & \\
\hline & Very & Negative & Neutral & Positive & Very \\
\hline & negative & 7 & 13 & 8 & positive \\
\hline & 2 & & & & 4 \\
\hline \multicolumn{6}{|c|}{ Collegial Relationships with the Department } \\
\hline \multirow{2}{*}{$\begin{array}{l}\text { During your time as chair, how } \\
\text { were collegial relationships } \\
\text { within the department? }\end{array}$} & Poor & Fair & Good & Very good & Excellent \\
\hline & 3 & 8 & 7 & 12 & 4 \\
\hline \multirow{2}{*}{$\begin{array}{l}\text { When you became chair, how } \\
\text { welcomed did you feel by the } \\
\text { previous chair? }\end{array}$} & $\begin{array}{l}\text { Not } \\
\text { welcomed }\end{array}$ & $\begin{array}{l}\text { Somewhat } \\
\text { welcomed }\end{array}$ & $\begin{array}{c}\text { Very } \\
\text { welcomed }\end{array}$ & & \\
\hline & 5 & 8 & 21 & & \\
\hline \multirow{2}{*}{$\begin{array}{l}\text { When you became chair, how } \\
\text { welcomed did you feel by your } \\
\text { department members? }\end{array}$} & $\begin{array}{l}\text { Not } \\
\text { welcomed }\end{array}$ & $\begin{array}{l}\text { Somewhat } \\
\text { welcomed }\end{array}$ & $\begin{array}{c}\text { Very } \\
\text { welcomed }\end{array}$ & & \\
\hline & 1 & 7 & 26 & & \\
\hline \multirow{2}{*}{$\begin{array}{l}\text { During your time as chair, to } \\
\text { what degree did your department } \\
\text { experience conflict? }\end{array}$} & Never & Rarely & Sometimes & Often & Always \\
\hline & 1 & 5 & 18 & 5 & 4 \\
\hline \multirow{2}{*}{$\begin{array}{l}\text { When you were department } \\
\text { chair, what was the climate in } \\
\text { your department among the } \\
\text { faculty? }\end{array}$} & Divided & Conflicted & Polite & Cordial & Friendly \\
\hline & 3 & 5 & 6 & 7 & 13 \\
\hline \multicolumn{6}{|c|}{ Ease of Contact with Administrators } \\
\hline \multirow{2}{*}{$\begin{array}{c}\text { Did you have regularly } \\
\text { scheduled meetings with your } \\
\text { Dean? }\end{array}$} & Yes & No & & & \\
\hline & 30 & 4 & & & \\
\hline \multirow{3}{*}{$\begin{array}{l}\text { If yes, how often did you have } \\
\text { these meetings? }\end{array}$} & Once a & Every other & Once a & Once a & Other \\
\hline & week & week & month & semester & 2 \\
\hline & 1 & 9 & 19 & 1 & \\
\hline \multicolumn{6}{|c|}{ Department Priorities and Goals } \\
\hline \multirow{2}{*}{$\begin{array}{l}\text { Identify your department's top } \\
\text { three priorities/goals. }\end{array}$} & \multicolumn{5}{|c|}{ Varied responses } \\
\hline & & & 30 & & \\
\hline \multirow[t]{2}{*}{ Have they changed over time? } & Yes & No & Not sure & & \\
\hline & 13 & 12 & 6 & & \\
\hline \multicolumn{6}{|c|}{ Nature of Chair Meetings } \\
\hline \multirow{2}{*}{$\begin{array}{l}\text { For college chair meetings with } \\
\text { the Dean, who primarily set the } \\
\text { agenda? }\end{array}$} & Dean & Chairs & Collaborati & Not sure & \\
\hline & 21 & 3 & $\begin{array}{l}\text { ve effort } \\
10\end{array}$ & 0 & \\
\hline \multicolumn{6}{|c|}{ Annual Review Process and Requirements } \\
\hline $\begin{array}{l}\text { In regard to writing the annual } \\
\text { program review, how did you }\end{array}$ & $\begin{array}{l}\text { Not at all } \\
\text { responsible }\end{array}$ & $\begin{array}{l}\text { Somewhat } \\
\text { responsible }\end{array}$ & $\begin{array}{l}\text { Mostly } \\
\text { responsible }\end{array}$ & $\begin{array}{l}\text { Completely } \\
\text { responsible }\end{array}$ & \\
\hline $\begin{array}{l}\text { perceive your responsibility in } \\
\text { writing the report? }\end{array}$ & 0 & 5 & 12 & 17 & \\
\hline $\begin{array}{l}\text { Approximately how much time } \\
\text { did you devote to compiling }\end{array}$ & & & aried response & & \\
\hline $\begin{array}{l}\text { information and writing the } \\
\text { annual program review? }\end{array}$ & & & 29 & & \\
\hline
\end{tabular}




\begin{tabular}{|c|c|c|c|c|c|}
\hline \multicolumn{6}{|c|}{ Assessment } \\
\hline \multirow{2}{*}{$\begin{array}{c}\text { Were you responsible for } \\
\text { department/program annual } \\
\text { assessment in addition to your } \\
\text { role as department chair? }\end{array}$} & Yes & No & Not sure & & \\
\hline & 15 & 18 & 1 & & \\
\hline \multicolumn{6}{|c|}{ Curricular Process } \\
\hline $\begin{array}{l}\text { How satisfied are you with } \\
\text { department chair involvement in } \\
\text { the curricular process? }\end{array}$ & $\begin{array}{c}\text { Very } \\
\text { dissatisfied } \\
2\end{array}$ & $\begin{array}{c}\text { Dissatisfied } \\
4\end{array}$ & $\begin{array}{c}\text { Unsure } \\
4\end{array}$ & $\begin{array}{l}\text { Satisfied } \\
21\end{array}$ & $\begin{array}{c}\text { Very } \\
\text { satisfied } \\
3\end{array}$ \\
\hline \multirow{2}{*}{$\begin{array}{l}\text { How familiar were you with the } \\
\text { curricular process before } \\
\text { becoming chair? }\end{array}$} & $\begin{array}{l}\text { Not at all } \\
\text { familiar }\end{array}$ & $\begin{array}{l}\text { Slightly } \\
\text { familiar }\end{array}$ & $\begin{array}{l}\text { Somewhat } \\
\text { familiar }\end{array}$ & $\begin{array}{l}\text { Moderately } \\
\text { familiar }\end{array}$ & $\begin{array}{l}\text { Extremely } \\
\text { familiar }\end{array}$ \\
\hline & 2 & 6 & 11 & 8 & 7 \\
\hline \multicolumn{6}{|c|}{ Release Time } \\
\hline $\begin{array}{l}\text { How satisfied with the amount } \\
\text { of release time you get as chair? }\end{array}$ & $\begin{array}{c}\text { Very } \\
\text { dissatisfied } \\
8\end{array}$ & $\begin{array}{c}\text { Dissatisfied } \\
9\end{array}$ & $\begin{array}{c}\text { Unsure } \\
2\end{array}$ & $\begin{array}{c}\text { Satisfied } \\
13\end{array}$ & $\begin{array}{c}\text { Very } \\
\text { satisfied } \\
2\end{array}$ \\
\hline \multirow{2}{*}{$\begin{array}{l}\text { If there were no release time for } \\
\text { being department chair, how } \\
\text { likely would you be to have } \\
\text { interest in this position? }\end{array}$} & $\begin{array}{l}\text { Extremely } \\
\text { unlikely }\end{array}$ & $\begin{array}{c}\text { Unlikely } \\
6\end{array}$ & $\begin{array}{c}\text { Neutral } \\
1\end{array}$ & $\begin{array}{c}\text { Likely } \\
2\end{array}$ & $\begin{array}{l}\text { Extremely } \\
\text { likely }\end{array}$ \\
\hline & 25 & & & & 0 \\
\hline \multicolumn{6}{|c|}{ Faculty Lines } \\
\hline \multirow{2}{*}{$\begin{array}{l}\text { At the time you were chair, what } \\
\text { percentage of your total faculty } \\
\text { were tenured/tenure track? }\end{array}$} & $0-25 \%$ & $26-50 \%$ & $51-75 \%$ & $76-100 \%$ & \\
\hline & 1 & 2 & 13 & 18 & \\
\hline
\end{tabular}

\section{Travel and Purchasing Process}

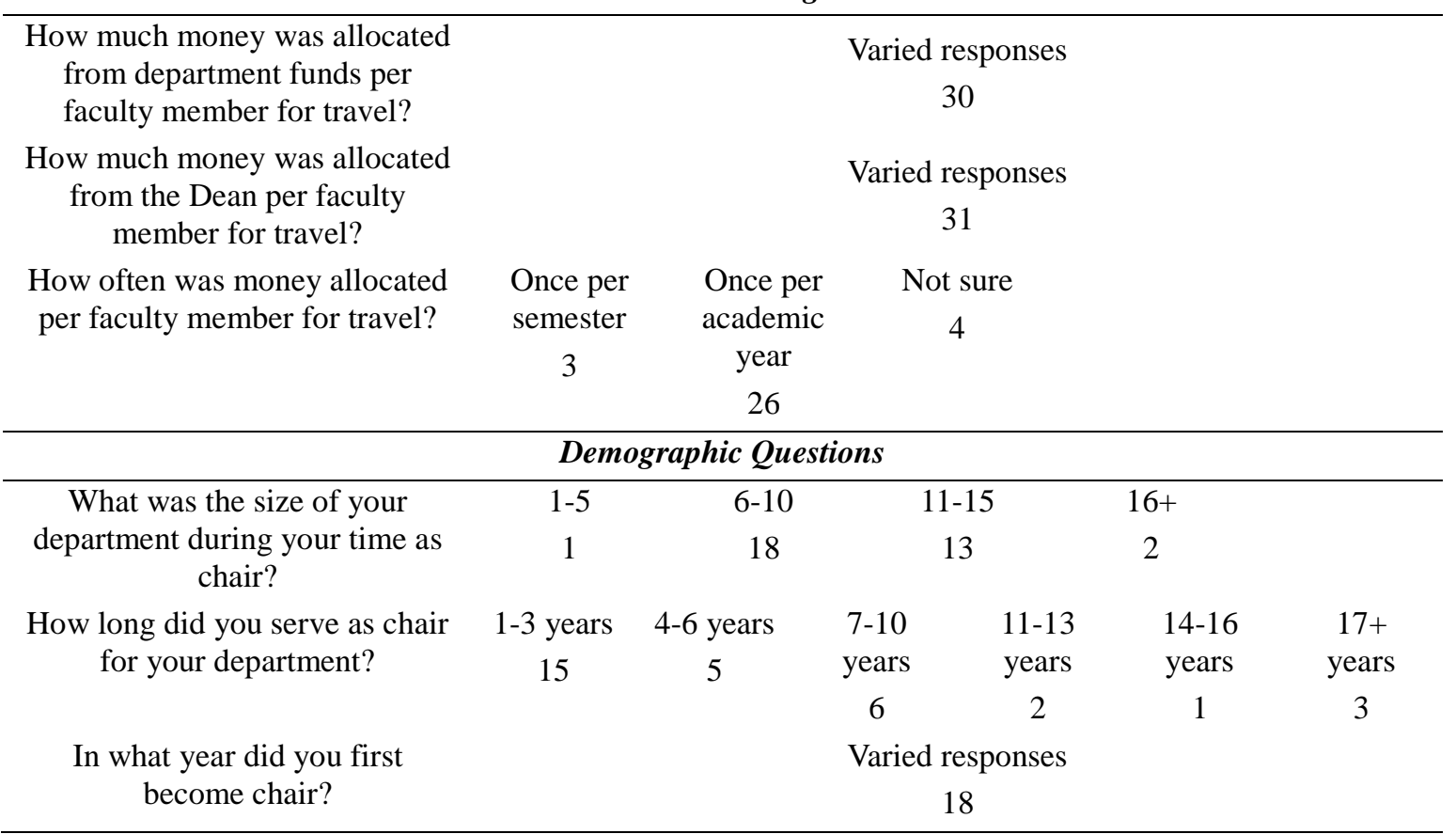

